\title{
Research article \\ Production of interleukin-1 receptor antagonist by human articular chondrocytes
}

\author{
Gaby Palmer ${ }^{1}$, Pierre-Andre Guerne ${ }^{1}$, Francoise Mezin ${ }^{1}$, Michel Maret ${ }^{1}$, Jerome Guicheux ${ }^{1,3}$, \\ Mary B Goldring ${ }^{2}$ and Cem Gabay ${ }^{1}$
}

\author{
${ }^{1}$ Division of Rheumatology, University Hospital, Geneva, Switzerland \\ ${ }^{2}$ New England Baptist Bone and Joint Institute and Rheumatology Division, Beth Israel Deaconess Medical Center, Harvard Institutes of Medicine, \\ Boston, Massachussetts, USA \\ 3Present address: INSERM EM 9903, School of Dental Surgery, Nantes, France
}

Correspondence: Cem Gabay, MD, Division of Rheumatology, University Hospital, 26 avenue de Beau-Sejour, 1211 Geneva 14, Switzerland. Tel: +4122382 3501; fax: +4122382 3509; e-mail: Cem.Gabay@hcuge.ch

Received: 25 October 2001

Revisions requested: 27 November 2001

Revisions received: 20 February 2002

Accepted: 11 March 2002

Published: 8 April 2002
Arthritis Res 2002, 4:226-231

(C) 2002 Palmer et al., licensee BioMed Central Ltd (Print ISSN 1465-9905; Online ISSN 1465-9913)

\begin{abstract}
Interleukin-1 receptor antagonist (IL-1Ra) is a natural IL-1 inhibitor possessing anti-inflammatory properties. IL-1Ra is produced as different isoforms, one secreted (sIL-1Ra) and three intracellular (iclL-1Ra1, iclL-1Ra2 and iclL-1Ra3), derived from the same gene. We examined the production of IL-1Ra species by cultured human articular chondrocytes in response to various cytokines. The levels of IL-1Ra were undetectable in culture supernatants of untreated cells, but were significantly increased by IL-1 $\beta$. Cell lysates contained very low levels of IL-1Ra, even in response to IL-1 $\beta$, suggesting that chondrocytes produce predominantly sIL-1Ra. IL-6, which had no effect on its own, enhanced the effect of IL-1 $\beta$, while dexamethasone prevented the response. We observed by RT-PCR that IL-1 $\beta$ and IL- 6 induced primarily the production of $s / L-1 R a$ mRNA. Furthermore, IL-1 $\beta$ alone or combined with IL-6 increased the levels of nascent unspliced s/L-1Ra mRNA, suggesting that sIL-1Ra expression is regulated at the transcriptional level. Reporter gene assays in immortalized chondrocytes, C-20/A4, consistently showed increased s/L-1Ra promoter activity in response to IL- $1 \beta$ and IL-6. In conclusion, human articular chondrocytes produce sIL-1 Ra in response to IL-1 $\beta$ and IL-6. The production of slL-1Ra by chondrocytes may have a protective effect against articular inflammatory and catabolic responses.
\end{abstract}

Keywords: cytokines, glucocorticoids, human articular chondrocytes, IL-1 receptor antagonist

\section{Introduction}

Interleukin-1 receptor antagonist (IL-1Ra) is a member of the IL-1 family that binds to IL-1 receptors but does not induce any intracellular response. IL-1Ra prevents the interaction between IL-1 and its cell surface receptors, and thus competitively inhibits the biological effects of IL-1 [1-3]. The administration of IL-1Ra ameliorates the course of arthritis in several experimental models [4]. In addition, therapeutic administration of IL-1Ra has beneficial effects in patients with rheumatoid arthritis [5].

$\mathrm{bp}=$ base pairs; C/EBP $=$ CCAAT/enhancer binding protein; DMEM $=$ Dubecco's modified Eagle's medium; ELISA = enzyme-linked immunosorbent assay; F12 = NUT.MIX.F-12 (HAM) Media; FCS = fetal calf serum; iclL-1Ra = intracellular IL-1 receptor antagonist isoform; IL = interleukin; $\mathrm{IL}-1 \mathrm{Ra}=\mathrm{IL}-1$ receptor antagonist; NF = nuclear factor; PCR = polymerase chain reaction; RT = reverse transcription; slL-1Ra $=$ secreted IL-1 receptor antagonist isoform; sIL-6R = soluble IL-6 receptor; SEM = standard error of the mean. 
IL-1Ra exists in four different isoforms derived from the same gene [6]. One isoform (sIL-1Ra) is secreted, while the three others (iclL-1Ra1, iclL-1Ra2 and iclL-1Ra3) are intracellular. The slL-1Ra and iclL-1Ra1 mRNAs are transcribed from different promoters and contain isoformspecific $5^{\prime}$ sequences due to alternative splicing $[7,8]$. The mRNA for iclL-1Ra2 is transcribed from the iclL-1Ra1 promoter, but contains an additional exon [9]. Finally, iclL-1Ra3 is produced by alternative translation initiation from the slL-1Ra transcript [10].

The expression of these various isoforms is cell-type specific and stimulus specific (see [6] for a review). In mice, sIL-1Ra is found predominantly in peripheral blood cells, the lungs, the spleen and the liver following lipopolysaccharide injection. iclL-1Ra1 is constitutively expressed in epithelial cells, and is inducible in monocytes and macrophages. The mRNA for iclL-1Ra2 has been detected in monocytes, neutrophils, keratinocytes and activated fibroblasts; however, the existence of a corresponding protein was never demonstrated. iclL-1Ra3 is produced in lipopolysaccharide-stimulated neutrophils and in monocytes.

The major biological role of extracellular sIL-1Ra is to modulate the effects of IL-1 at the cell surface. The intracellular isoforms may be released from cells under some circumstances, but have also been suggested to perform important regulatory roles within cells.

IL-1 plays an important role in the mechanisms leading to cartilage breakdown by increasing the production of matrix metalloproteinases and by inhibiting the production of type II collagen and aggrecan $[11,12]$. Exogenous administration of IL-1Ra exerts chondroprotective effects in different in vitro and in vivo models [13-15]. However, little information is available on local IL-1Ra production in cartilage [16]. In addition, IL-1Ra isoforms expressed in chondrocytes have not been characterized. The aim of the present study was to gain further information on the regulation of IL-1Ra isoform production by human articular chondrocytes in response to various cytokines.

\section{Materials and methods Materials}

Cell culture reagents and DNAse I were purchased from Life Technologies AG (Basel, Switzerland). Cytokines were obtained from R\&D Systems (Abingdon, Oxon, UK) and dexamethasone from Sigma (Fluka Chemie AG, Buchs, Switzerland). FuGENE 6 was purchased from Roche Molecular Biochemicals (Rotkreuz, Switzerland).

\section{Cell culture}

Cartilage was obtained from patients undergoing joint replacement for osteoarthritis and was cultured as previously described (see Supplementary material for details) $[17,18]$. C-20/A4-immortalized human chondrocytes [19] were cultured in high-glucose (4.5 g/l) DMEM/F12 (1:1, $\mathrm{v} / \mathrm{v})$, supplemented with $10 \%$ FCS.

\section{ELISA for human IL-1Ra}

Freshly isolated or subcultured chondrocytes were seeded in 96 -well plates $(40,000$ cells/well). After incubation with cytokines, culture supernatants were collected and cell lysates were obtained after three cycles of freezing and thawing. IL-1Ra concentrations in supernatants and lysates were measured by ELISA [20]. The sensitivity of this assay is $78 \mathrm{pg} / \mathrm{ml}$. Results shown are the mean \pm SEM of three determinations in a representative experiment.

\section{RNA isolation and RT-PCR}

Total RNA was prepared using the Tripure reagent (Roche Molecular Biochemicals). RNA $(3 \mu \mathrm{g})$ was reversetranscribed using avian myeloblastosis virus-RT, and PCR was performed using appropriate primer pairs and conditions (see Supplementary material).

\section{Reporter gene assays}

C-20/A4 cells were transfected with $0.4 \mu \mathrm{g}$ plasmid DNA using the FuGENE 6 reagent (see Supplementary material for details). Luciferase activity was determined with the assay system from Promega (Wallisellen, Switzerland) and was normalized for protein content measured with the protein assay reagent from BioRad (Reinach, Switzerland). Results shown are the mean \pm SEM of three determinations in a representative experiment.

\section{Statistical analysis}

The significance of differences was calculated by analysis of variance.

\section{Results}

\section{IL-1Ra production in articular chondrocytes}

IL-1Ra production was assessed in culture supernatants and lysates of chondrocytes incubated with various cytokines. Similar results were obtained with freshly isolated chondrocytes and with subcultured cells used after one to seven passages. IL-1Ra was undetectable in supernatants of untreated cells, but IL-1 $\beta$ stimulated its production (Fig. 1). IL-1Ra secretion was first detected after 24 hours of stimulation and increased progressively for at least 72 hours (Fig. 1a). IL-6, which had no effect on its own, enhanced the stimulatory effect of IL-1 $1 \beta$. The response to $\mathrm{IL}-1 \beta$, alone or combined with IL-6, was dose dependent (Fig. 1b). In these experiments, IL-6 was used in combination with its soluble receptor (sIL-6R), which is present in a high amount in the synovial fluid. Furthermore, as recently demonstrated, the presence of slL-6R is required for full responsiveness of chondrocytes to IL-6 [21].

IL-4, IL-10, and transforming growth factor (TGF)-beta $(10 \mathrm{ng} / \mathrm{ml})$, used either alone or in the presence of IL-1 $\beta$, 


\section{Figure 1}

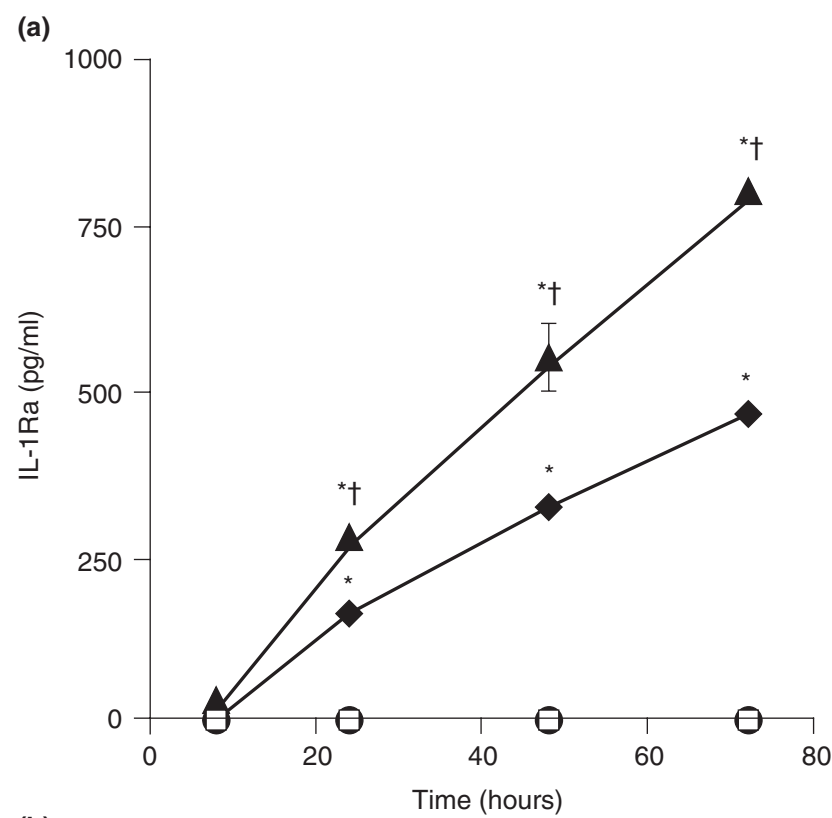

(b)

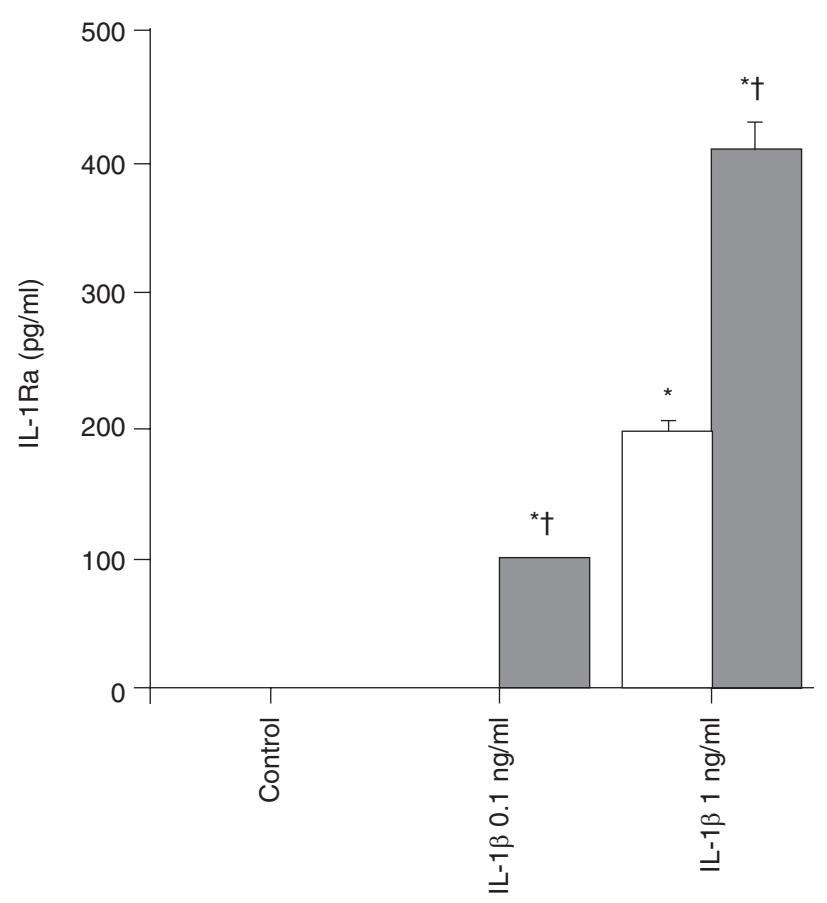

IL-1 $\beta$ and IL- 6 stimulate IL-1Ra production. (a) Chondrocytes (passage 3) were left unstimulated (open squares), or were stimulated with $1 \mathrm{ng} / \mathrm{ml} \mathrm{IL-1 \beta}$ (filled diamonds), with $10 \mathrm{ng} / \mathrm{ml} \mathrm{IL-6}$ and $100 \mathrm{ng} / \mathrm{ml}$

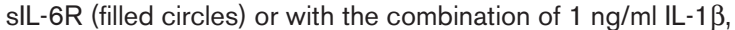
$10 \mathrm{ng} / \mathrm{ml} \mathrm{IL-6}$ and $100 \mathrm{ng} / \mathrm{ml}$ slL-6R (filled triangles). IL-1Ra concentrations in culture supernatants were measured by ELISA. ${ }^{\star} P<0.01$ versus control at the same time point, ${ }^{\dagger} P<0.01$ versus IL-1 $\beta$-treated cells at the same time point. (b) Chondrocytes (passage 1) were stimulated with the indicated doses of IL-1 $\beta$ alone (white bars) or with IL-1 $1 \beta$ combined with $10 \mathrm{ng} / \mathrm{ml} \mathrm{IL-} 6$ and $100 \mathrm{ng} / \mathrm{ml}$ slL-6R (grey bars) for 72 hours. ${ }^{*} P<0.01$ versus control, ${ }^{\dagger} P<0.01$ versus the same dose of IL-1 $\beta$ alone. were devoid of any stimulatory effect on IL-1Ra production (data not shown).

Cell lysates contained very low levels of IL-1Ra, which were mostly below the detection limit of our ELISA, even after stimulation with $\mathrm{IL}-1 \beta$ and IL-6/slL-6R (data not shown). These results suggest that articular chondrocytes produce essentially the secreted isoform, slL-1Ra.

Dexamethasone $\left(10^{-7} \mathrm{M}\right)$ specifically inhibited the stimulatory effect of IL-1 $\beta$ and IL-6/sIL-6R on IL-1Ra production (see Supplementary material).

\section{Expression of IL-1Ra mRNA}

We investigated the expression of slL-1Ra and iclL-1Ra1 transcripts by RT-PCR using isoform-specific primers. $\mathrm{IL}-1 \beta$ induced sIL-1Ra mRNA production, and this effect was enhanced by IL-6 (Fig. 2a). In contrast, dexamethasone inhibited the induction of slL-1Ra mRNA by IL-1 $\beta$ and IL-6. In one experiment, these relative levels of sIL-1Ra mRNA expression were confirmed by quantitative real-time PCR (Fig. 2b). The presence of iclL-1Ra1 mRNA could also be detected in response to IL-1 $\beta$ and IL-6, but at lower levels as compared with slL-1Ra mRNA. Dexamethasone also decreased its expression (Fig. 2a). This result is consistent with the low levels of IL-1Ra protein in cell lysates.

To assess whether the observed increase in steady-state sIL-1Ra mRNA expression was due to increased gene transcription, we examined the levels of nascent unspliced sIL-1Ra mRNA (Fig. 3). IL-1 $\beta$ alone or in combination with IL-6/sIL-6R induced the expression of nascent slL-1Ra mRNA, thereby suggesting that slL-1 Ra gene transcription was increased.

\section{Activity of the human $1680 \mathrm{bp}$ sIL-1Ra promoter in chondrocytes}

We studied SIL-1Ra promoter activity in transiently transfected C-20/A4 chondrocytes using the enh-1680 construct (see Supplementary material for more detailed information). This construct exhibited constitutive reporter gene expression in C-20/A4 cells, which was significantly increased by the combination of IL- $1 \beta$ and IL-6/sIL-6R (Fig. 4). These findings are consistent with our results showing increased secretion of IL-1Ra protein and induction of slL-1Ra mRNA in response to IL-1 $\beta$ and IL-6.

\section{Discussion}

In the present paper, we report that human articular chondrocytes produce IL-1Ra in response to IL-1 $\beta$, thereby confirming a previously published observation [16]. In addition, IL- 6 in combination with its soluble receptor slL-6R enhanced this response, while IL-4, IL-10 and TGF-beta were devoid of any stimulatory effect. Cell lysates contained very little IL-1Ra, suggesting that 
Figure 2

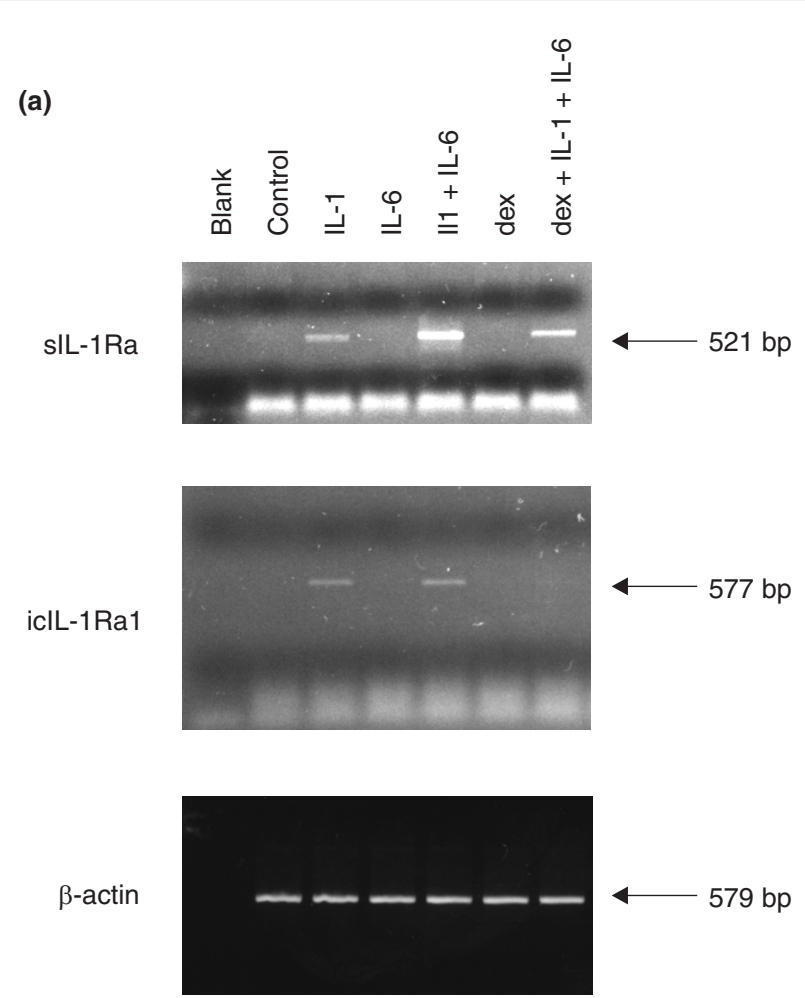

(b)

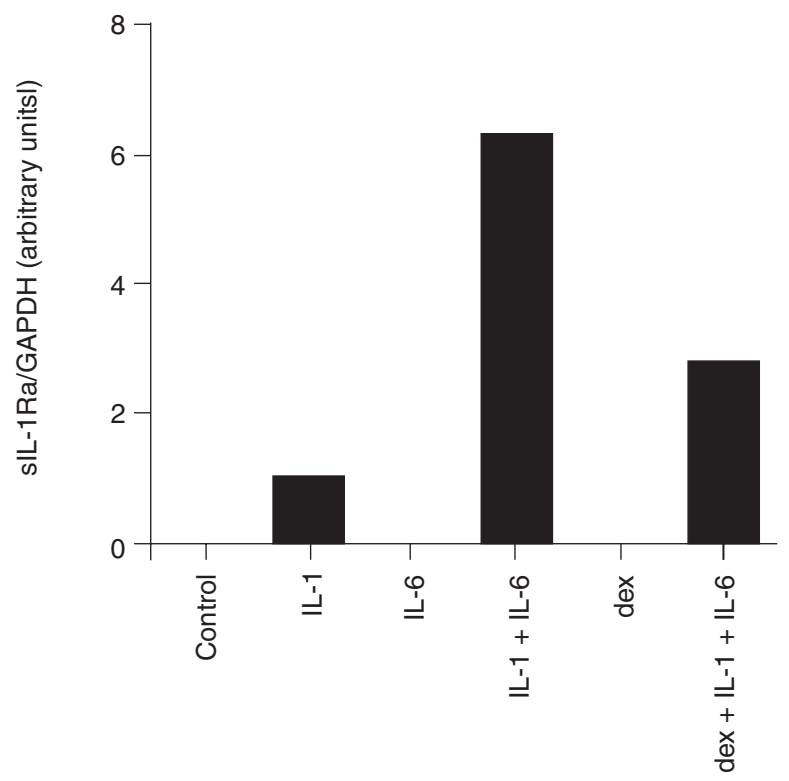

Effect of IL-1 $\beta$, IL- 6 and dexamethasone on sIL-1Ra and iclL-1Ra1 mRNA expression. (a) Chondrocytes (passage 5) were left unstimulated (control) or were stimulated for 18 hours with $1 \mathrm{ng} / \mathrm{ml}$ IL-1 1 (IL-1), with $10 \mathrm{ng} / \mathrm{ml} \mathrm{IL-6}$ and $100 \mathrm{ng} / \mathrm{ml}$ sIL-6R (IL-6) or with $10^{-7} \mathrm{M}$ dexamethasone (dex). Blank, distilled water was used as the negative control. (b) In one experiment, expression levels of slL-1Ra were assessed by quantitative real-time PCR. The graph shows slL-1Ra expression corrected for glyceraldehyde-3-phosphate dehydrogenase (GAPDH) levels.

\section{Figure 3}

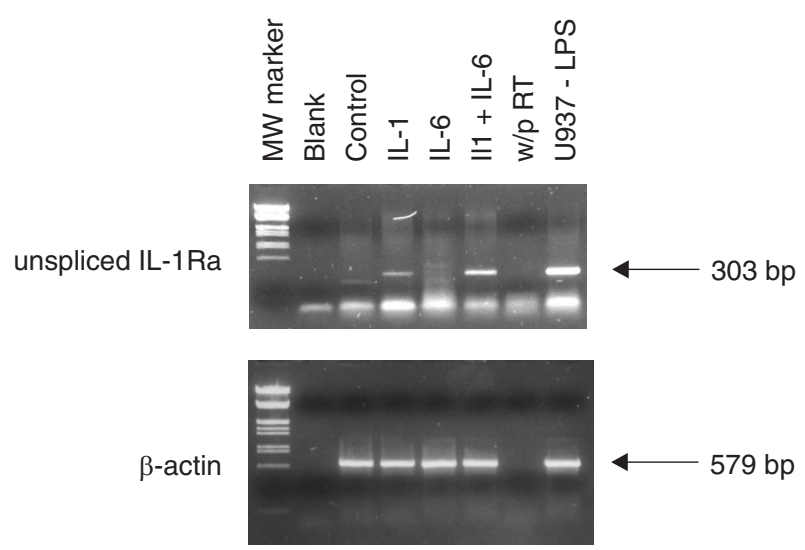

IL-1 $\beta$ and IL- 6 increase the expression of nascent sIL-1Ra transcripts. Chondrocytes (passage 5) were stimulated as described in Figure 2. Blank, distilled water; w/o RT, PCR performed on nonreversetranscribed RNA from IL-1 $\beta$-stimulated and IL-6-stimulated cells as a control to exclude genomic DNA contamination; U937-LPS, lipopolysaccharide-stimulated U937 monocytic cells used as positive control. MW, molecular weight.

\section{Figure 4}

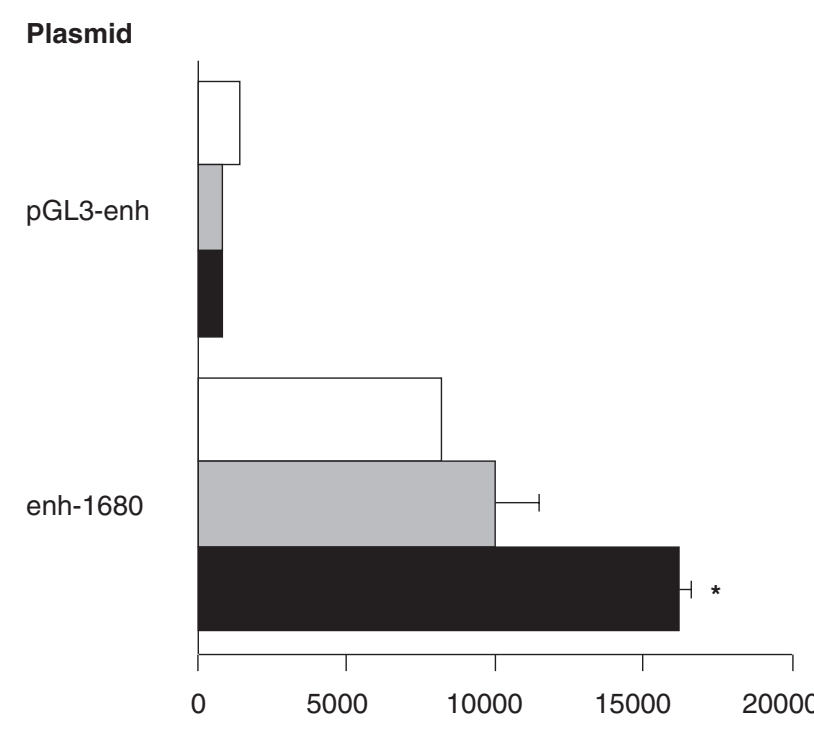

Light units/ $\mu$ g proteins

IL-1 $\beta$ and IL- 6 stimulate human sIL-1Ra promoter activity. C-20/A4 cells were transfected with the enh-1680 reporter gene construct. Negative controls were performed using empty pGL3-enhancer (pGL3-enh). Cells were left unstimulated (white bars), or were stimulated with $1 \mathrm{ng} / \mathrm{ml} \mathrm{IL-1} \beta$ (grey bars) or with a combination of $1 \mathrm{ng} / \mathrm{ml} \mathrm{IL-1 \beta ,10} \mathrm{ng/ml} \mathrm{IL-6} \mathrm{and}$ $100 \mathrm{ng} / \mathrm{ml}$ slL-6R (black bars) for 48 hours. ${ }^{\star} P<0.001$ versus unstimulated cells transfected with the same plasmid. 
chondrocytes mainly produce the secreted isoform. Using specific primers, we confirmed that articular chondrocytes produce predominantly slL-1Ra mRNA.

A similar stimulation of sIL-1Ra production by IL-1 $\beta$, which was also enhanced by IL-6, was observed in hepatocytes, allowing the classification of IL-1Ra as an acute phase protein [20]. In both hepatocytes and chondrocytes, IL-1 $\beta$ and IL- 6 stimulated sIL-1Ra expression at the level of gene transcription. Furthermore, this response was shown to be mediated by activation of NF-KB and CCAAT/enhancer binding protein $(\mathrm{C} / \mathrm{EBP})$ in hepatocytes. Interactions between the two transcription factors NF-KB and C/EBP have been suggested to mediate the synergistic effects of IL-1 and IL- 6 on acute phase protein production [20].

Glucocorticoids have been reported to increase or decrease IL-1Ra production depending on the cell type $[20,22]$. In chondrocytes, we observed a specific inhibition of IL-1Ra expression by dexamethasone. This finding suggests that IL-1Ra does not contribute to the antiinflammatory effect of glucocorticoids in the cartilage.

The physiologic function of endogenous IL-1Ra has been clearly demonstrated in several studies using IL-1Ra gene knockout mice, which have an earlier onset of collageninduced arthritis and more severe synovitis, often accompanied by tissue damage [23]. Furthermore, when bred into the BALB/cA background, IL-1Ra knockout mice develop spontaneous chronic polyarthritis, reproducing some of the clinical and biological features of rheumatoid arthritis [24]. These findings suggest that IL-1Ra plays an important role in the modulation of articular inflammation and in subsequent cartilage breakdown. Our results show that IL-1Ra is produced by articular chondrocytes in response to IL-1 and IL-6, two cytokines present in significant amount in inflamed joints. Secreted IL-1Ra in turn then probably modulates the effects of IL-1 in the cell microenvironment. Local production of IL-1Ra might thus be part of a negative feedback mechanism initiated by these cytokines and may exert a chondroprotective effect against IL-1-mediated cartilage lesions during physiologic and pathologic processes, including rheumatoid arthritis and osteoarthritis.

\section{Conclusion}

Human articular chondrocytes produce slL-1Ra in response to IL-1 $\beta$ and IL-6. This effect reflects increased transcription from the slL-1Ra promoter. The local production of slL-1Ra in cartilage may have a protective effect against articular inflammatory and catabolic responses.

\section{Acknowledgements}

Gaby Palmer and Pierre-Andre Guerne contributed equally to this work. The authors thank Cristiana Juge for her help with quantitative real-time PCR and Nathalie Pellegrinelli for her expert technical assistance. This work was supported by the Swiss National Science Foundation (grant 3100-064123.00/1 to PAG, and grants 3200-054955.98 and 3231-05454.98 to CG) and the Albert-Boeni Foundation.

\section{References}

1. Dripps DJ, Brandhuber BJ, Thompson RC, Eisenberg SP: Interleukin-1 (IL-1) receptor antagonist binds to the $80-\mathrm{kDa}$ IL-1 receptor but does not initiate IL-1 signal transduction. $J \mathrm{Bio}$ Chem 1991, 266:10331-10336.

2. Granowitz EV, Clark BD, Mancilla J, Dinarello CA: Interleukin-1 receptor antagonist competitively inhibits the binding of interleukin-1 to the type II interleukin-1 receptor. J Biol Chem 1991, 266:14147-14150.

3. Greenfeder SA, Nunes P, Kwee L, Labow M, Chizzonite RA, Ju G: Molecular cloning and characterization of a second subunit of the interleukin 1 receptor complex. J Biol Chem 1995, 270: 13757-13765.

4. Gabay C: IL-1 inhibitors: novel agents in the treatment of rheumatoid arthritis. Expert Opin Investig Drugs 2000, 9:113127.

5. Bresnihan B, Alvaro-Gracia JM, Cobby M, Doherty M, Domljan Z, Emery P, Nuki G, Pavelka K, Rau R, Rozman B, Watt I, Williams B, Aitchison R, McCabe D, Musikic P: Treatment of rheumatoid arthritis with recombinant human interleukin-1 receptor antagonist. Arthritis Rheum 1998, 41:2196-2204.

6. Arend WP, Malyak M, Guthridge CJ, Gabay C: Interleukin-1 receptor antagonist: role in biology. Annu Rev Immunol 1998, 16:27-55.

7. Hannum $\mathrm{CH}$, Wilcox CJ, Arend WP, Joslin FG, Dripps DJ, Heimdal PL, Armes LG, Sommer A, Eisenberg SP, Thompson RC: Interleukin-1 receptor antagonist activity of a human interleukin-1 inhibitor. Nature 1990, 343:336-340.

8. Haskill S, Martin G, Van Le L, Morris J, Peace A, Bigler CF, Jaffe GJ, Hammerberg C, Sporn SA, Fong S, Arend WP, Ralph P: cDNA cloning of an intracellular form of the human interleukin 1 receptor antagonist associated with epithelium. Proc Nat Acad Sci USA 1991, 88:3681-3685.

9. Muzio M, Polentarutti N, Sironi M, Poli G, De Gioia L, Introna M, Mantovani A, Colotta F: Cloning and characterization of a new isoform of the interleukin 1 receptor antagonist. $J$ Exp Med 1995, 182:623-628.

10. Malyak M, Guthridge JM, Hance KR, Dower SK, Freed JH, Arend WP: Characterization of a low molecular weight isoform of IL1 receptor antagonist. J Immunol 1998, 161:1997-2003.

11. Goldring MB, Birkhead J, Sandell LJ, Kimura T, Krane SM: Interleukin 1 suppresses expression of cartilage specific types II and IX collagens and increases types I and III collagens in human chondrocytes. J Clin Invest 1988, 82:2026-2037.

12. Tyler JA: Articular cartilage cultured with catabolin (pig interleukin 1) synthetizes a decreased number of normal proteoglycan molecules. Biochem J 1985, 227:869-878.

13. Baragi VM, Renkiewicz RR, Jordan H, Bonadio J, Hartman JW, Roessler BJ: Transplantation of transduced chondrocytes protects articular cartilage from interleukin 1-induced extracellular matrix degradation. J Clin Invest 1995, 96:2454-2460.

14. Fernandes J, Tardif G, Martel-Pelletier J, Lascau-Coman V, Dupuis M, Moldovan F, Sheppard M, Krishnan BR, Pelletier JP: In vivo transfer of interleukin-1 receptor antagonist gene in osteoarthritic rabbit knee joints: prevention of osteoarthritis progression. Am J Pathol 1999, 154:1159-1169.

15. Muller-Ladner U, Roberts CR, Franklin BN, Gay RE, Robbins PD, Evans $\mathrm{CH}$, Gay S: Human IL-1Ra gene transfer into human synovial fibroblasts is chondroprotective. J Immunol 1997, 158:3492-3498.

16. Pelletier JP, Mineau F, Ranger P, Tardif G, Martel-Pelletier J: The increased synthesis of inducible nitric oxide inhibits IL-1ra synthesis by human articular chondrocytes: possible role in osteoarthritic cartilage degradation. Osteoarthritis Cartilage 1996, 4:77-84.

17. Lotz M, Clark-Lewis I, Ganu V: HIV-1 transactivator protein Tat induces proliferation and TGF beta expression in human articular chondrocytes. J Cell Biol 1994, 124:365-371.

18. Klareskog L, Forsum U, Malmnas Tjernlund UK, Kabelitz D, Wigren A: Appearance of anti-HLA-DR-reactive cells in normal and rheumatoid synovial tissue. Scand J Immunol 1981, 14: 183-192. 
19. Goldring MB, Birkhead JR, Suen LF, Yamin R, Mizuno S, Glowacki J, Arbiser JL, Apperley JF: Interleukin-1 beta-modulated gene expression in immortalized human chondrocytes. $J$ Clin Invest 1994, 94:2307-2316.

20. Gabay C, Smith MF, Eidlen D, Arend WP: Interleukin 1 receptor antagonist (IL-1Ra) is an acute-phase protein. J Clin Invest 1997, 99:2930-2940.

21. Guerne PA, Desgeorges A, Jaspar JM, Relic B, Peter R, Hoffmeyer P, Dayer JM: Effects of IL-6 and its soluble receptor on proteoglycan synthesis and NO release by human articular chondrocytes: comparison with IL-1. Modulation by dexamethasone. Matrix Biol 1999, 18:253-260.

22. Sauer J, Castren M, Hopfner U, Holsboer F, Stalla GK, Arzt E: Inhibition of lipopolysaccharide-induced monocyte interleukin-1 receptor antagonist synthesis by cortisol: involvement of the mineralocorticoid receptor. J Clin Endocrinol Metab 1996, 81:73-79.

23. Ma Y, Thornton S, Boivin GP, Hirsh D, Hirsch R, Hirsch E: Altered susceptibility to collagen-induced arthritis in transgenic mice with aberrant expression of interleukin-1 receptor antagonist. Arthritis Rheum 1998, 41:1798-1805.

24. Horai R, Saijo S, Tanioka H, Nakae S, Sudo K, Okahara A, Ikuse T, Asano M, Iwakura Y: Development of chronic inflammatory arthropathy resembling rheumatoid arthritis in interleukin 1 receptor antagonist-deficient mice. J Exp Med 2000, 191:313320.

\section{Supplementary material}

\section{Supplementary materials and methods Cell culture}

Cartilage was obtained from patients undergoing knee joint or hip joint replacement for osteoarthritis. Chondrocytes were isolated by collagenase digestion, as previously described [17,18], and cultured in DMEM containing L-glutamine, streptomycin, penicillin and 10\% FCS. Isolated chondrocytes were either used immediately or were expanded and subcultured several times. Cells were stimulated with cytokines 24 hours after seeding.

\section{Proteoglycan synthesis}

Proteoglycan synthesis was evaluated by measuring the aggrecan concentration in culture supernatants by enzyme-amplified sensitivity immunoassay (Biosource Europe S.A., Nivelles, Belgium). Results are presented as the mean \pm SEM of three determinations.

\section{Reverse transcription polymerase chain reaction}

RNA was digested with DNAse I and reverse-transcribed using avian myeloblastosis virus-RT and random hexamer primers (Promega). PCR (40 cycles for IL-1Ra isoforms and unspliced transcript, 35 cycles for $\beta$-actin) was performed using appropriate primer pairs (Supplementary Figure 1 and Supplementary Table 1) and appropriate conditions (Supplementary Table 2). The identity of the amplified products was confirmed by DNA sequencing. RT-PCR experiments performed on chondrocyte cultures from four different patients yielded similar results. Quantitative real-time PCR for slL-1Ra was performed with a Light Cycler ${ }^{\mathrm{TM}}$ (Roche Molecular Biochemicals, Basel, Switzerland), using primers B and G (Supplementary Figure $S 1$ and Supplementary Table S1). Expression of sIL-1Ra mRNA was corrected for glyceraldehyde-3-phosphate dehydrogenase levels, which were amplified using the indicated primers (Supplementary Table 1) and conditions (Supplementary Table 2).

\section{Reporter gene assays}

The 1680 bp human slL-1Ra promoter region was recovered from plasmid psRA1680 [20] by digestion with Hindlll, and it was inserted upstream of the luciferase reporter gene in pGL3-enhancer (Promega) to yield plasmid enh-1680. Correct insertion of the promoter fragment was verified by DNA sequencing. C-20/A4 cells were seeded in 24-well plates (20,000 cells/well) and transfected 24 hours later in DMEM containing 1\% FCS with $0.4 \mu \mathrm{g}$ DNA and $1.2 \mu \mathrm{l}$ FuGENE 6. After 4 hours, cells were switched to DMEM/F12 containing 10\% FCS. Cytokines were added 24 hours after transfection.

\section{Supplementary results Specific inhibition of IL-1Ra production by dexamethasone}

Dexamethasone $\left(10^{-7} \mathrm{M}\right)$ inhibited the stimulatory effect of IL-1 $\beta$ and IL-6/sIL-6R on IL-1Ra production (Supplementary Figure 2a). This inhibitory effect of dexametha-

\section{Supplementary Figure 1}

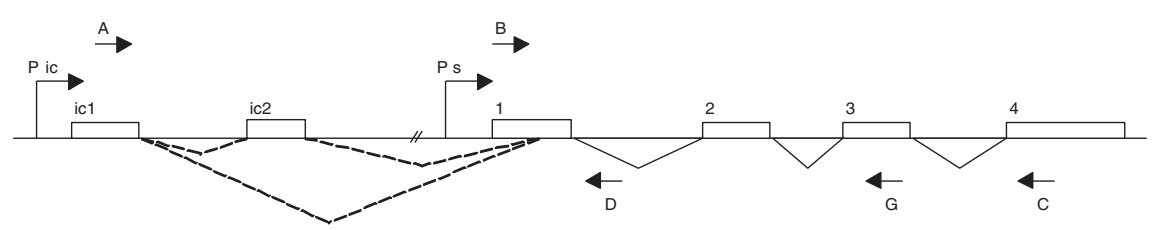

Schematic representation of the human IL-1RN gene. The IL-1RN gene contains six exons, which are represented by boxes. The iclL-1Ra1 and iclL-1Ra2 mRNAs are transcribed from a promoter $(P$ ic) located upstream of exon ic1. The iclL-1Ra1 transcript contains exon ic1 spliced to an internal splice acceptor site within exon 1, followed by exons 2 to 4 . The iclL-1Ra2 mRNA contains an additional exon (ic2) inserted downstream of exon ic1. This differential splicing is symbolized by dotted lines. The slL-1Ra mRNA is transcribed from a promoter (Ps) located immediately upstream of exon 1 and contains exons 1 to 4 . The locations of PCR primers A-D and G (Supplementary Table 1) are indicated by arrows. The combination of primers $A$ and $C$ allows specific amplification of iclL-1Ra1 and iclL-1Ra2 cDNAs, while primers $B$ and $C$ or $B$ and $G$ specifically amplify sIL-1Ra mRNA. The combination of primers $B$ and D allows the detection of unspliced primary slL-1Ra transcripts. 
Supplementary Table 1

\begin{tabular}{|c|c|c|c|c|}
\hline Primer & Gene & GenBank & Location $(b p)^{*}$ & Sequence $5^{\prime}-3^{\prime}$ \\
\hline$A$ & $I L-1 R N$ & U65590 & $16,106-16,131(\mathrm{~s})$ & CAGGTACTGCCCGGGTGCTACTTTAT \\
\hline B & $I L-1 R N$ & U65590 & $25,827-25,852(s)$ & GGCCTCCGCAGTCACCTAATCACTCT \\
\hline $\mathrm{C}$ & $I L-1 R N$ & U65590 & $30,881-30,856$ (as) & TACTACTCGTCCTCCTGGAAGTAGAA \\
\hline $\mathrm{D}$ & $I L-1 R N$ & U65590 & $26,130-26,109$ (as) & GGTCGCACTATCCACATCTGGG \\
\hline$E$ & $\beta$-Actin & M10277 & $1559-1583(\mathrm{~s})$ & CCAAGGCCAACCGCGAGAAGATGAC \\
\hline $\mathrm{F}$ & $\beta$-Actin & M10277 & $2681-2658$ (as) & AGGGTACATGGTGGTGCCGCCAGAC \\
\hline $\mathrm{G}$ & $I L-1 R N$ & U65590 & 29134-29115 (as) & TTGACACAGGACAGGCACAT \\
\hline $\mathrm{H}$ & GAPDH & M32599 & $140-157(\mathrm{~s})$ & AACGACCCCTTCATTGAC \\
\hline I & GAPDH & M32599 & 330-312 (as) & TCCACGACATACTCAGCAC \\
\hline
\end{tabular}

*Sense (s) or antisense (as) orientation with respect to the corresponding gene is indicated. GAPDH, glyceraldehyde-3-phosphate dehydrogenase.

Supplementary Table 2

\section{PCR conditions}

\begin{tabular}{lcccc}
\hline cDNA & Forward primer & Reverse primer & Annealing temperature $\left({ }^{\circ} \mathrm{C}\right)$ & Product length (bp) \\
\hline iclL-1Ra1 & A & C & 55 & 577 \\
slL-1Ra & B & C & 55 & 521 \\
Unspliced IL1-Ra & B & D & 55 & 303 \\
B-Actin & E & F & 60 & 579 \\
slL-1Ra (LC) & B & G & 57 & 268 \\
GAPDH (LC) & H & I & 57 & 191 \\
\hline
\end{tabular}

LC, Light CyclerTM (Roche Molecular Biochemicals, Basel, Switzerland). GAPDH, glyceraldehyde-3-phosphate dehydrogenase.

sone was dose dependent and was already present at a concentration of $10^{-9} \mathrm{M}$ (data not shown). In contrast, dexamethasone significantly enhanced proteoglycan synthesis (Supplementary Figure 2b), indicating that the inhibitory effect of dexamethasone on IL-1Ra production was specific and not secondary to cell toxicity.

\section{Activity of the human 1680 bp sIL-1Ra promoter in chondrocytes}

The enh-1680 reporter construct contains $1680 \mathrm{bp}$ human sIL-1Ra promoter region (Supplementary Figure 1, region $\mathrm{Ps}$ ). This region was shown previously to contain DNA cis-acting elements responsible for cell-type-specific expression of slL-1Ra [20]. It contains, in particular, binding sites for the transcription factors NF- $\kappa B$ and $\mathrm{C} / \mathrm{EBP}$, which are involved in the activation of SIL-1Ra transcription by IL-1 and IL-6 in HepG2 cells [20]. Human osteoarthritis chondrocytes are difficult to transfect [S1] and our transfection efficiencies were not sufficient to yield detectable luciferase activities using the enh-1680 plasmid. As an alternative, we used C-20/A4-immortalized human chondrocytes for these experiments. These cells exhibit responses to IL-1 similar to those described in primary human chondrocytes [19].

\section{Supplementary reference}

S1. Madry H, Trippel SB: Efficient lipid-mediated gene transfer to articular chondrocytes. Gene Ther 2000, 7:286-291. 
(a)

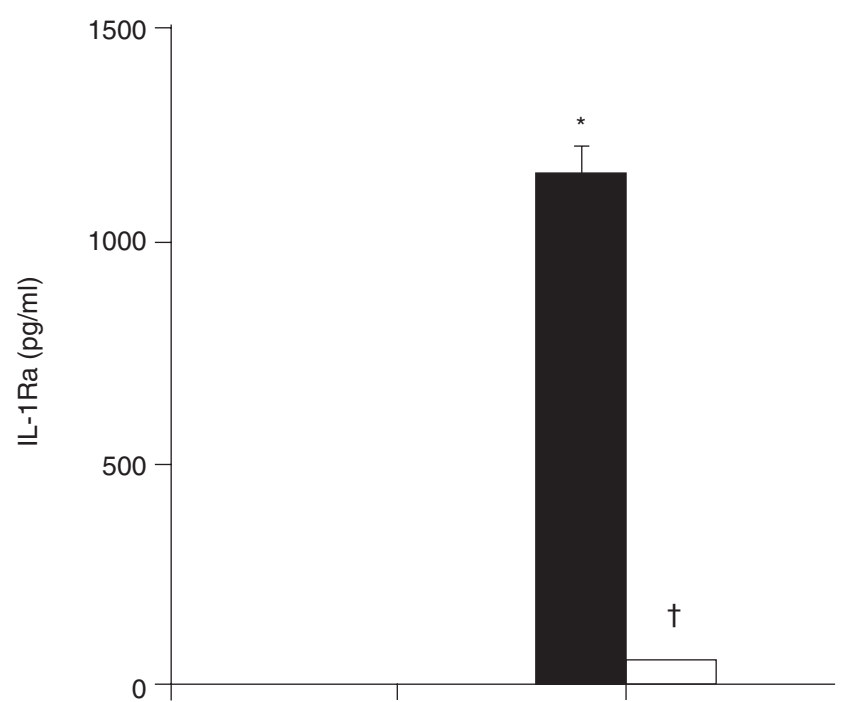

(b)

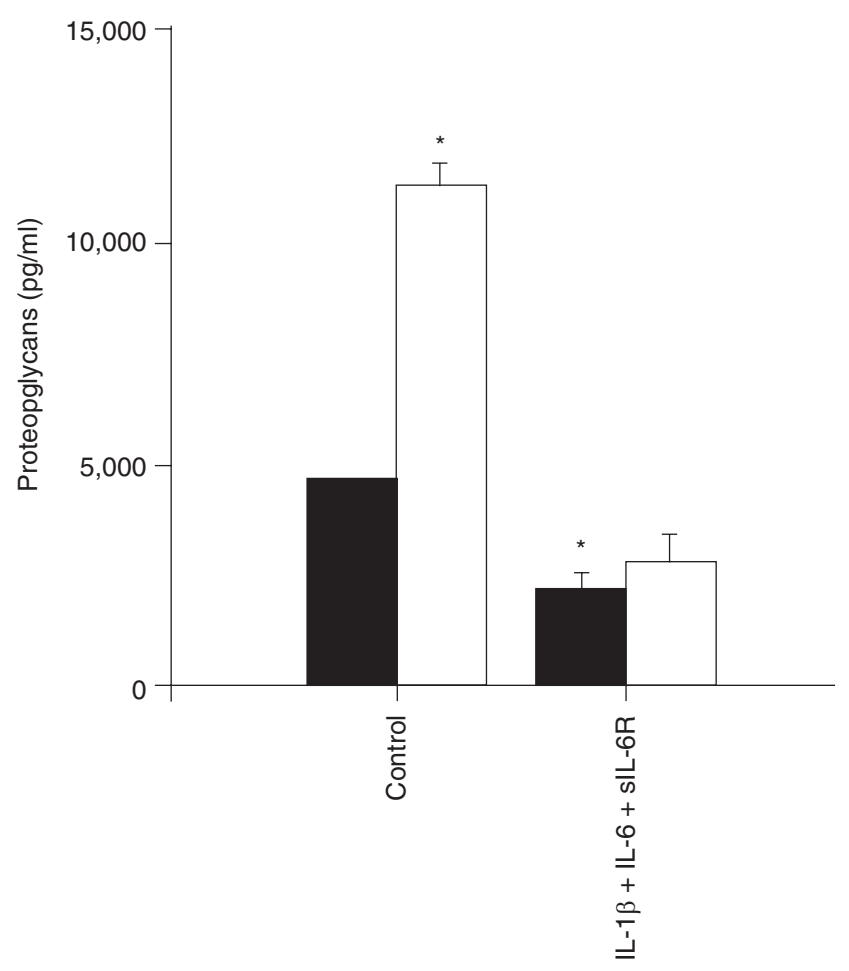

Specific inhibition of IL-1Ra production by dexamethasone. (a) Freshly isolated chondrocytes were stimulated with $1 \mathrm{ng} / \mathrm{ml} \mathrm{IL-} 1 \beta, 10 \mathrm{ng} / \mathrm{ml}$ IL-6 and $100 \mathrm{ng} / \mathrm{ml}$ slL-6R for 72 hours in the absence (black bars) or presence (white bars) of $10^{-7} \mathrm{M}$ dexamethasone. ${ }^{\star} P<0.001$ versus control without dexamethasone, ${ }^{\dagger} P<0.001$ versus IL-1 $\beta$, IL- 6 and slL-6R without dexamethasone. (b) Proteoglycan content was measured in the culture supernatants used for IL-1Ra determination. ${ }^{*} P<0.01$ versus control without dexamethasone. 